\title{
The Archaeological Search for Tartessos-Tarshish-Atlantis and Other Human Settlements in the Donana National Park
}

\author{
Rainer W. Kühne \\ Tuckermannstr. 35, 38118 Braunschweig, Germany \\ kuehne70@gmx.de
}

April 7, 2011

\begin{abstract}
Adolf Schulten suggested that Tartessos-Tarshish was the model for Plato's Atlantis. I argued that its capital was situated in what is now the Marisma de Hinojos within the central part of the Andalucian Donana National Park in south-west Spain. This article reports about the preliminary results of an archaeological expedition to test this theory. The preliminary results of the expedition include evidence of either a tsunami or a storm flood during the third millenium BC and evidence of human settlements from the Neolithic Age to the Middle Ages.
\end{abstract}

\section{Geological Situation and Literary Evidence}

According to previous geological investigations, the marismas of the Donana National Park have been submarine since the end of the last Ice Age. Because of sedimentation they became marshy islands within the Lacus Ligustinus either already during the Roman times [1] or as late as the Middle Ages [2]. As a consequence, no permanent human settlement has been possible in the marismas until recently.

On the other hand, previous studies provided literary evidence of ancient cultures within the Donana National Park. These cultures include Tartessos, Tarshish, and Atlantis [3].

The capital of Tartessos was situated between the two mouths of the river Baetis (Strabon 3.1.9; 3.2.11; Pausanias 6.19.3). The Baetis was tidal and Iberia's largest river (Pausanias 6.19.3). Baetica was the ancient Roman name of Andalucia (cf. Pliny 3.6). Therefore it is reasonable to identify the Baetis with Andalucia's largest river, the Guadalquivir, and to locate the capital of Tartessos close to its present opening, i. e. within the Donana National Park.

Tarshish was mentioned in several books of the bible. It was mentioned either as a state or a landscape (Gen. 10.4; 1 Chr. 1.7; 2 Chr. 9.21; 20.36-37; 
Ps. 72.10; Isa. 23.6; 23.10; 66.19; Jer. 10.9; Ezek. 27.12; 38.13; Jon. 1.3; 4.2). A special kind of trade ship was named after Tarshish (1 Kgs. 10.22; 22.49; Ps. 48.8; Isa. 2.16; 23.1; 23.14; 60.9; Ezek. 27.25). Moreover a jewel (Exod. 28.20; 39.13) and persons (1 Chr. 7.10; Est. 1.14) were named after Tarshish. The state of Tarshish was mentioned by inscriptions of the Assyrian king Asarhaddon of the 7th century BC and by the Phoenician Nora stone in Sardinia from around 800 BC. Tarshish has often been identified with Tartessos. Both Tartessos (Herodotus 4.152; Diodorus 5.35.4) and Tarshish (1 Kgs. 10.22; 2 Chr. 9.21; Isa. 60.9; Jer. 10.9; Ezek. 27.12) were rich in silver. Both Tartessos (Diodorus 5.35.4) and Tarshish (1 Kgs. 10.22; 2 Chr. 9.21; Ezek. 27.12) traded with the Phoenicians.

Atlantis was a philosophical fiction of the ancient Greek philosopher Plato [4]. He intended to describe his fictional ideal state in the case of war (Tim. 19c). Plato transferred his ideal state to ancient Athens (Tim. 26c-d) and its opponent to Atlantis.

Tartessos was suggested as the model for Plato's description of the capital and geography of Atlantis [3]. According to Plato, Atlantis was situated in the Atlantic Sea (Tim. 24e), i. e. the Atlantic Ocean, beyond (Crit. 108e) and in front of (Tim. 24e) the Pillars of Heracles, i. e. the Strait of Gibraltar (cf. Pliny 3.4), and facing the Gadirean country (Crit. 114b), i. e. the city of Cadiz. The capital was situated 50 stades, i. e. 9 kilometres, from the sea (Crit. 113c; Crit. 115d). It was situated within a large rectangular plain (Crit. 118c) which had a south coast (Crit. 118a-b). It is reasonable to identify this plain with the rectangular valley of the Guadalquivir south-west of Sevilla and to locate the model for the capital of Atlantis within the Donana National Park.

\section{Preliminary Results of the Archaeological Ex- pedition}

Media reports on the possible location of Tartessos-Atlantis in the Donana National Park [5] motivated a team of researchers to perform two expeditions in the Donana National Park. The first one lasted from 9 to 14 July 2006. The second one lasted five weeks from mid August to mid September 2009.

The team was both interdisciplinary and international. It included archaeologist Sebastian Celestino Perez, archaeologist Tomas Cordero Ruiz, biologist Jose-Antonio Lopez-Saez, archaeologist Victorino Mayoral Herrera, historian and anthropologist Juan Jose R. Villarias Robles, archaeologist Enrique Cerrillo, cartographer Jose Angel Martinez, all of the Consejo Superior de Investigaciones Cientificas (CSIC), historian Angel Leon Conde of the Fundacion Hogar del Empleado (FUHEM), and geologist Antonio Rodriguez-Ramirez of the University of Huelva.

This team was joined by historian Richard Freund of the Maurice Greenberg Center for Judaic Studies of the University of Hartford, geographer Philip Reeder of the University of South Florida, geophysicists Paul Bauman, Jennifer 
MacDonald and Laurie Pankratow, all of Worley Parsons, Calgary, Canada. Services were hired from the Deutsches Zentrum fr Luft- und Raumfahrt (DLR) located in Braunschweig, VORSEVI, S. A. located in Camas near Sevilla, and International Geophysical Technology (IGT), S. L. located in San Sebastian de los Reyes near Madrid.

The two expeditions have the project numbers $17 / 2005$ and $18 / 2009$ of the Estacion Biologica de Donana of the CSIC.

The expeditions were financially supported by the Fundacion Caja de Madrid, the Fundacion Donana 21, the Town Council of Hinojos, and the institutions of the team members. The work of the University of Hartford and Worley Parsons was financially supported by Simcha Jacobovici's film company Associated Producers located in Toronto, Canada. Their documentary about this expedition was commissioned by the National Geographic Channel and broadcasted the first time on 13 March 2011.

The licences for the expeditions were approved by both the Grupo de Trabajo de Investigacion del Parque Nacional de Donana and the Consejeria de Cultura de la Junta de Andalucia.

The area of investigation included the Pacil de Cardales, the Horno del Mal Tiempo, Las Vetillas, and the Veta Carrizosa. All these areas are situated within the Marisma de Hinojos which lies in the central part of the Donana National Park.

The tasks of the expeditions included an archaeological survey, test excavations, geological drillings including sediment analysis, pollen analysis and microfaunal analysis, radiocarbon dating, aerial photos taken from a pilotless airplane and a balloon, and geophysical tests including ground penetrating radar, magnetometry and electric resistivity tomography.

The archaeological survey in the Pacil de Cardales and the Horno del Mal Tiempo yielded many pottery sherds in both areas. Typologically they date from the Muslim period from the 8th to the 13th century AD. Two clay statuettes detected in the Horno del Mal Tiempo date typologically from the Roman Imperial time, but were probably deposited there much later. Pieces of a pottery-made plate detected in the southern part of the Cano de Cardales date from the Visigothic period, 5th to 8th century AD.

The test excavations consisted of two ditches in the Veta Carrizosa and one in the Pacil de Cardales. All three excavations yielded pottery sherds which date typologically from the Neolithic Age, the Copper Age, and the early Bronze Age. Paleolithic artifacts detected in the southern part of the Pacil de Cardales provide evidence of a settlement which was smaller than one hectar.

Geological drillings up to depths of 18 metres in the Veta Carrizosa yielded a sand layer in the clay subsoil. This provides evidence of a high energy event, either a tsunami or a storm flood, during the third millenium BC.

Aerial photos showed several rectangular forms in the Horno del Mal Tiempo and several rectangular and circular forms in the Pacil de Cardales. The lengths of the rectangular forms vary between 20 and 230 metres. The diameters of the circular forms are about 100 metres.

Of particular interest is one rectangular form with a length of 45 metres 
and a width of 40 metres which is situated at $36^{\circ} 57^{\prime} 53^{\prime \prime} \mathrm{N}$ and $6^{\circ} 21^{\prime} 48^{\prime \prime} \mathrm{W}$ in the Horno del Mal Tiempo. Aerial photos provide evidence that the form has been surrounded by a rectangular ditch. Pottery sherds and fragments of building rocks were detected within this form during the archaeological survey of July 2006. The two above-mentioned clay statuettes were detected within this rectangular form in 2009.

The geophysical tests provided further evidence of man-made forms in the Horno del Mal Tiempo and the Pacil de Cardales. Within one circular form situated at $36^{\circ} 56^{\prime} 38^{\prime \prime} \mathrm{N}$ and $6^{\circ} 22^{\prime} 32^{\prime \prime} \mathrm{W}$ in the Pacil de Cardales regular patterns are shown in the variation of the degree of resistivity to electric currents at a depth of 3 to 5 metres underground. A fragment of a brick, probably from the 12 th or 13 th century AD, was discovered on the surface of this form.

A rectangular form with a length of 230 metres and a width of 140 metres situated at $36^{\circ} 57^{\prime} 27^{\prime \prime} \mathrm{N}$ and $6^{\circ} 23^{\prime} 06^{\prime \prime} \mathrm{W}$ in the northern part of the Pacil de Cardales has previously been interpreted as a possible remain of the silver temple devoted to Poseidon and described by Plato (Crit. 116c-d). It is an elevation with a height of some 30 centimetres above the surrounding area.

Further work is required in order to decide whether the rectangular and circular forms seen in the aerial photos of the Pacil de Cardales are remains of the capital of Tartessos.

\section{References}

[1] F. Ruiz et al., "The Geological Record of the Oldest Historical Tsunamis in Southwestern Spain", Rivista Italiana di Paleontologia e Stratigrafia 114 (2008) 145-154.

[2] A. Rodriguez-Ramirez and C. M. Yanez-Camacho, "Formation of chenier plain of the Donana marshland (SW Spain): Observations and geomorphic model", Marine Geology 254 (2008) 187-196.

[3] A. Schulten, Tartessos, ein Beitrag zur ältesten Geschichte des Westens (Hamburg, Friederichsen, 1922).

A. Schulten, "Tartessos und Atlantis", Petermanns geographische Mitteilungen 73 (1927) 284-288.

A. Schulten, "Atlantis", Rheinisches Museum fr Philologie 88 (1939) 326346.

R. W. Kühne, "A location for Atlantis?", Antiquity online 78, 300 (2004). R. W. Kühne, "Did Ulysses Travel to Atlantis?", in: Science and Technology in Homeric Epics, ed. S. A. Paipetis. Series: History of Mechanism and Machine Science, Vol. 6 (Springer Press, 2008) pp. 509-514.

[4] E. S. Ramage (ed.), Atlantis - Fact or Fiction? (Indiana University Press, 1978).

P. Y. Forsyth, Atlantis - The Making of Myth (McGill-Queen's University Press, 1980). 
[5] M. Shermer, "The Myth is the Message", Scientific American 291, 4 (October 2004) p. 19.

anonymous, "Atlantis", New Scientist 204, 2736 (28 November 2009) p. 42. S. Lovgren, "Atlantis Evidence Found in Spain and Ireland", National Geographic online (19 August 2004).

anonymous, "Caso Atlantida: se reabre la hipotesis andaluza", GEO (Madrid) 213 (September 2004) p. 22.

J. Gill, Andalucia - A Cultural History (Oxford University Press, 2008) pp. 19-20. 